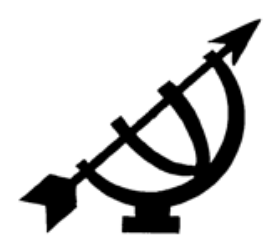

\title{
The Polokwane conference and South Africa's second political transition: tentative conclusions on future perspectives
}

\section{J.C.M. Venter}

Research Fellow: Focus Area Social Transformation

Potchefstroom Campus

North-West University

POTCHEFSTROOM

E-mail: 10214844@nwu.ac.za

\author{
A. Duvenhage \\ Research Director: Focus Area Social Transformation \\ Potchefstroom Campus \\ North-West University \\ POTCHEFSTROOM \\ E-mail: Andre.Duvenhage@nwu.ac.za
}

\begin{abstract}
The Polokwane conference and South Africa's second political transition: tentative conclusions on future perspectives
\end{abstract}

In this phase of South Africa's second political transition (manifesting characteristics of political decay) it looks as if the ANC is becoming more dominant, hegemonic and ideological, with added neo-patrimonial tendencies that are becoming more overt in an oligarchic manner. This article analyses the ANC's Polokwane conference (qualitatively and deductively) as part of South Africa's second political transition since 1994 and postulates potential outcomes (scenario perspectives).

Opsomming

Die Polokwane-konferensie en Suid-Afrika se tweede politieke transisie: tentatiewe konklusies rondom toekomsperspektiewe

In die fase wat as Suid-Afrika se tweede transisie voorgehou kan word (met kenmerke van institusionele verval), kom dit voor 
asof die ANC polities meer dominant word, sterker hegemonies en ideologies handel, met neo-patrimoniale eienskappe wat sterker na die oppervlak kom en oligargies manifesteer. Hierdie artikel analiseer die ANC se Polokwane-konferensie (kwalitatief en deduktief) as onderdeel van Suid-Afrika se tweede politieke transisie sedert 1994 en beredeneer potensiële uitkomstes (scenario perspektiewe) in hierdie verband.

\section{Introduction}

During the Jacob Zuma trial(s) and especially in the post-Polokwane era, the language of the ANC (African National Congress), SACP and COSATU alliance (tripartite alliance) changed in a remarkable and unsettling way. Examples of the new political rhetoric include:

Julius Malema, speaking at a Youth Day rally vowing that "... the youth of South Africa would die in supporting ANC president Jacob Zuma" (SAPA, 2008a). Malema continued at a funeral of a former ANCYL (African National Congress Youth League) president: “... Remnants of the counter-revolution including the Democratic Alliance and those opposed to Jacob Zuma becoming SA's next president must be eliminated ..." (SAPA, 2008b). Before a Zuma court appearance in September 2008: "If you don't leave Jacob Zuma alone we will make this country ungovernable ...", attributed to an unknown member of the protest group from the ANCYL outside the court as they burnt an effigy of Thabo Mbeki (SAPA, 2008c). This type of language was also levelled against Mosiuoa Lekota and other members of COPE. According to Mbanjwa (2008), supporters of Zuma chanted "kill Shilowa, kill Lekota" outside the Orange Farm venue where Lekota was holding a public meeting. Lekota and his supporters had to be escorted by police into and out of the venue. At other meetings, physical confrontations between the ANC and Lekota's supporters broke out and police had to restore order (SAPA, 2008d). Zwelinzima Vavi, COSATU's Secretary-General went on record saying: "I am not going to waste my time with human rights champions of yesterday" when asked about his exhortation to kill for Zuma (quoted by Mkhwanazi, 2008).

More recently, the ANCYL proclaimed that they were disgusted by the remarks of "... the racist girl Helen Zille" who has "... appointed an all-male Cabinet of useless people, the majority of whom are her boyfriends and concubines so that she can continue to sleep around with them ...". Umkhonto we Sizwe veterans weighed in with a threat to make the Western Cape ungovernable: "Should Helen Zille not refrain from this anti-Africa and racist behaviour, we are not 
going to hesitate, but craft and launch a political program aimed at rendering the Western Cape ungovernable" (SAPA, 2009).

After years of democracy and the Nelson Mandela and Mbeki eras, this type of behaviour and language marked a sharp return to the rhetoric of revolution and contributed to the process through which, at the Polokwane conference, the leadership of the ANC changed by way of what amounts to a palace revolution. 1 This rhetoric no doubt contributed to the redeployment of Mbeki and the resulting Zuma presidency, described in this article as the "second political transition". 2 The main wellsprings of rhetoric are ideologies that are built around the basic interests of the most important groups in society and that determine the relationship of the party to the rest of the political system (Ball, 1993:88; Newton \& Van Deth, 2005:241).

Thus, the central theoretical statement that this article proposes is that in the phase that can be described as South Africa's second political transition, wherein characteristics of institutional decay can be recognised, the ANC is becoming more dominant, hegemonic and ideological and that these tendencies manifest in a neo-patrimonialist and oligarchic fashion. Against this background, it is therefore the goal of this article to analyse (reconstruct and interpret) the effects of the Polokwane conference, which ignited South Africa's second political transition and emphasised the underlying recommitment to the leitmotif of the national democratic revolution (NDR), on the ANC, regime and state.

This is done through a deductive and qualitative process. The conceptual framework explained focuses on the concepts of a state with a dominant-party system (as is exemplified by South Africa and the ANC), the role of ideology and the concept of transition. These theoretical perspectives are first examined and explained, in order to

1 According to the Oxford English Dictionary Online (2009), a palace revolution is "the (freq. non-violent) overthrow of a sovereign or government, esp. by senior members of the ruling group". This is in contrast to a democratic transition, which can be defined as "... the change from non democratic to democratic government, usually by the existence of at least one free and fair election" (Ferguson, 2006:352).

2 The first political transition in modern South Africa was the transition away from apartheid towards multiparty democracy, formalised in 1994 . The current postPolokwane era denotes the period in which political power has been transferred from the Mbeki faction of the ANC to the Zuma faction, with the resulting changes in policy, government and party structures, which for the purposes of this article is termed the "second political transition". 
provide tools for the understanding of the historical chronological events leading up to the Polokwane conference, the main decisions made at Polokwane, and the subsequent second political transition of South Africa through the general election of 2009. In order to achieve these goals, the following areas are addressed:

- conceptualisation and theoretical perspectives on the second political transition;

- a reconstruction of the events leading up to the National conference of the ANC at Polokwane;

- the main decisions of the National conference of the ANC at Polokwane;

- the 2009 elections: Polokwane brought to the nation;

- the second political transition in South Africa; and

- conclusions.

The aim of the following section is to provide a description of concepts, theoretical perspectives and their relationships, thereby providing a theoretical point of departure for the article and subsequent analysis of the South African political environment.

\section{Conceptualisation and theoretical perspectives: parties within dominant-party systems}

Political parties seek to win political power and to exercise that power (Duverger, 1955:xxiii) within a greater whole (Sartori, 1976: 25). Newton and Van Deth (2005:221) elaborate, stating that political parties are organisations of politically like-minded people who seek political power and public office, in order to realise their policies. Parties in democracies have two central purposes: to gain power by winning elections, and once in power, to implement their public policy, which is a general set of ideas or plans that has been officially agreed on and which is used as a basis for making decisions (Duverger, 1955:xxiii-xxiv; Newton \& Van Deth, 2005:222). As political parties seek to gain political power or to stay in power, parties and politicians know that they must win the support, if not the hearts and minds, of their citizens (Ball, 1993:79). This is accomplished through ideologies built around the basic interests of the most important groups in society and which determine the relationship of the party to the rest of the political system (Ball, 1993:88; Newton \& Van Deth, 2005:241). Ideology is defined as a systematic, 
well-developed and comprehensive set of ideas and beliefs about politics consisting of a reconstruction of the current unacceptable situation, a reconstruction of an ideal situation in conflict with the unacceptable status quo, and a socio-political programme of change that will remould the unacceptable present into the ideal future (Newton \& Van Deth, 2005:242). As such, political parties and ideologies are engaged in a struggle for the position of dominance that will allow them to govern or influence government. Sartori (1976:72) distinguishes between the inter- (between parties) political system and the intra- (within the party) political system. The struggle for power described above exists on both these levels. An example of the interparty relations is the (conflictual) relationships between the ANC and other groupings that possess a political motivation or agenda. Intraparty relations are the (sometimes conflictual) relationships between (among others) rival power centres in the party, as was seen between Mbeki and Zuma and is now seen, to a different extent, between Trevor Manuel and Gwede Mantashe.

A transition occurs when one ideology, party or party faction supplants the other. This can be done in a democratic or non-democratic way. The two ways that this can occur that are relevant to this article are through a palace revolution, which is a coup d'état executed by those already in positions of power, or a democratic transition, which in contrast usually includes at least one free and fair election (Ferguson, 2006:352). The inter- and intrarelations of parties described above, form the systems in which political parties operate.

Party systems, the whole that Sartori (1976:25) speaks of, are patterns of significant parties within a more comprehensive political system (Newton \& Van Deth, 2005:224). A political system is a system wherein political demands and support are converted to political decisions and policy (Cloete et al., 2006:40; cf. Easton, 1953). As such, a political system is a structural-functional model designed to explain political survival, maintenance, decay, and collapse (Bealey, 2003:260). The manner and modes of the coexistence of different parties in the political system form the party system (Duverger, 1955:203). In order to classify party systems, Sartori (1976:125) suggests starting with what he terms numerical criteria; however, according to Sartori this sole criterion is insufficient to describe the complexity of factors involved when classifying party systems. The major criterion for the classification of party systems is rather the level of competition within the system (Sartori, 1976:xi). 
Competitive politics is conditioned not only by the presence of more than one party but also by a minimum of fair competition ... below which a political market can hardly perform as a competitive market (Sartori, 1976:140).

Ball (1993:91), acknowledging the complexity of the subject as described by Sartori, uses the following criteria: the number of parties; the relative strength of parties; the ideological difference between parties; and the structure of the party. These result in the following classification: one-party systems (Cuba, China and North Korea), dominant-party systems (India, Japan), distinct two-party systems (New Zealand), indistinct two-party systems (the United States), two and one-half party systems, a stable multiparty system and unstable multiparty systems (Ball, 1993:91). The system most relevant to the subject of this article is the dominant-party system.

Dominant-party systems differ from one-party systems in that a party can become so dominant in a multiparty environment that an election victory is considered a formality. Examples of this are India and the Indian Congress Party, Italy and the Christian Democratic Party, Sweden and the Social Democratic Party, the National Party rule in South Africa from 1948 to 1994, and now the ANC in South Africa from 1994 "until Jesus comes back", in the words of Zuma (Plowright, 2008).

On this point, Gentili (2005:8) offers another valuable distinction. Even a dominant-party system as defined above is not necessarily hegemonic. In a dominant-party system, change of government is still possible, whilst in a hegemonic system the party in control begins monitoring other parties to such an extent that these parties can no longer be termed competitors and change of government become impossible, except by regime change. Sartori (1976:127) describes a hegemonic party as one that permits the existence of other parties only as subordinates, thereby limiting competition on interand intraparty levels and thus democracy within the party system and within the party (Sartori, 1976:140). Because there is no competition for votes (alternatives), there is limited or no democracy (cf. Schumpeter, 1942:269).

A dominant political party as described above becomes a de facto political elite, a group who is in some way superior to the rest of the community, which is the essence of oligarchy as defined by Michels (1959:21) and Duverger (1955:4), signifying governance by a small 
organised minority or elite. ${ }^{3}$ In order to understand South African politics in its current form, the following theoretical points need to be explained.

An example of elite governance (oligarchy) and a hallmark of African politics is patrimonialism (Bratton \& Van De Walle, 1998:61; Thompson, 2003:9). South Africa under the apartheid system serves as an example of this and is classified as a Settler oligarchy by Bratton and Van de Walle (1998:78) and a Totalitarian race oligarchy by Adam (1971:37-47).

In determining this classification, Bratton and Van de Walle (1998: 77) use only two criteria to classify African party systems in general: political participation and political competition. The result of this classification is illustrated in Figure 1 below.

\section{Figure 1: African party systems}

(Bratton \& Van de Walle, 1998:78)

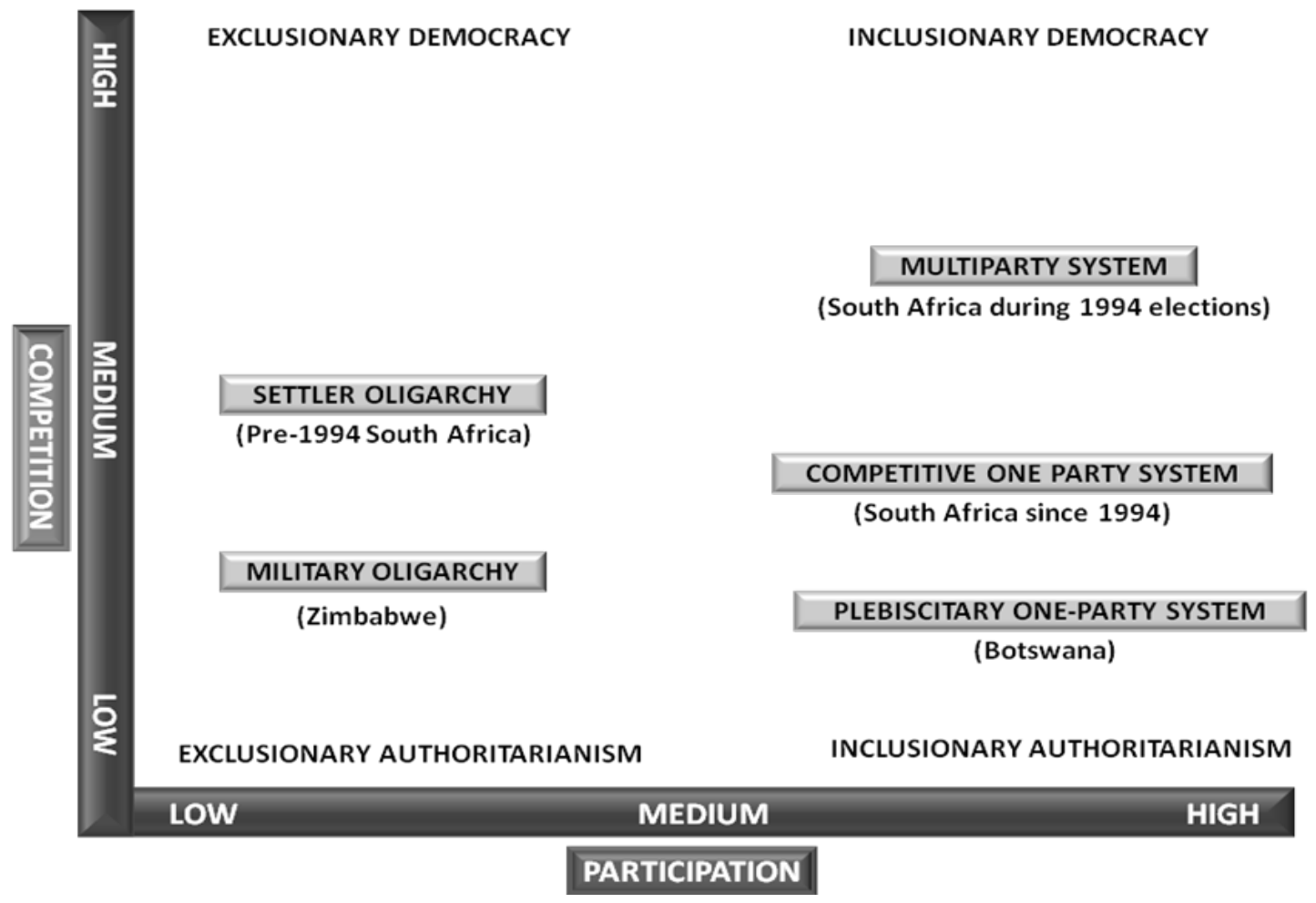

The types of regimes identified by Bratton and Van de Walle (1998: 78-82), are all forms of neo-patrimonial rule characterised by neo-

3 In a dominant-party system, there are elites within elites. On the interparty (party system) level, the dominant party is an elite grouping, whilst on the intraparty level, the organisational elite manage the party (Sartori, 1976:71). 
patrimonialism. ${ }^{4}$ A neo-patrimonial system according to this viewpoint is a hybrid political system "... in which the customs and patterns of patrimonialism co-exist with, and suffuse, rational-legal institutions" (Bratton \& Van de Walle, 1998:62). Patrimonialism is the concentration of power in the personal authority of the leader, whilst Western regimes logic focus on the supremacy of institutions as illustrated by the belief in, among other principles related to democratic practice, the trias politica (cf. Thompson, 2003:107; Bratton \& Van de Walle, 1998:61). In opposition to this point of departure, patrimonial leaders treat all political concerns of the state as their own personal affairs; the state is their private property (Thompson, 2003:107). The current (2008/2009) situation in Zimbabwe under the leadership of Robert Mugabe serves as an example. The underlying perspective of this example can be described as neo-patrimonialist, which differs fundamentally from a Western conceptualisation with far-reaching implications for the number of parties, the relative strength of parties, the ideological difference between parties, and the structure of the party, as identified by Ball (1993:91).

There is a fundamental dichotomy between Western state regime logic and patrimonial regime logic. Western regime logic focuses on institutions of government and democracy, whilst the focus of neopatrimonial regime logic centres on the individual and big-man or strongman politics. The former was brought to Africa by colonialism and forms a part of the legacy of apartheid in South Africa. Patrimonialism has its roots in strongman politics that became a characteristic of postcolonial Africa (Thompson, 2003:1070). Neopatrimonialism is the intertwining and fusion (synergy) of these two sets of characteristics, producing a form of personal rule (Thompson, 2003:107). This fusion is situational and example specific; in other words no two neo-patrimonial regimes will necessarily be the same.

Postcolonial Africa has been dominated by personal rule or patrimonialism - this encourages competition among intragovernmental factions (Thompson, 2003:110). Regimes with a neo-patrimonial orientation need sources of legitimacy, which include violence that

4 These regimes, as shown in Figure 1, are a plebiscitary one-party system, which allows limited competition and high participation. The military oligarchy is exclusionary, whilst the competitive one-party system allows more competition. Settler oligarchies are exclusionary democratic, as a part of society has access to the democratic process, whilst multiparty systems have high levels of participation and competition. 
feeds the root of counter-violence. Therefore, the skilful personal ruler uses a combination of coercion and legitimacy, $\mathbf{5}$ to maintain government order and social order. Personal rulers rely on the distribution of state resources to buy legitimacy for their regimes. As long as patrons can nourish their followers through the manipulation of public goods and institutions, with the use of praetorian measures (that is, the military or quasi-military, such as militias; Huntington, 2006:195), they are safe. Ethiopia, Somalia and Zimbabwe serve as extreme examples where as a result of, among other things, neopatrimonialism, the formal political system imploded. Reward for clients distributed through the mechanism of clientelism becomes the substitute for legitimacy (Thompson, 2003:111). Clientelism is a relation of exchange between unequals. It is a mutually beneficial association between the powerful and the weak. A patron extends public office (a salary and access to the state), security and resources to his clients. The primary agent of state coercion is the military or quasi-military. The intervention of the military in politics or praetorianism, along with patrimonialism and clientelism, can be viewed (from a Western regime logic) as symptoms of political decay. An extreme example of this is the 2008 Zimbabwe crisis where system implosion occurred.

The essential background of political decay is a distinction that Huntington (2006:1) offers of the difference of countries regarding their degree of government as measured by the government's ability to provide security and stability. Political decay occurs when political institutions can no longer cope with or regulate political participation and security and stability atrophies. 6 Patrimonialism, praetorianism and clientelism are all forces that seek legitimacy for weak states or government in the absence of, and whilst eroding the legal-rational institutions of government, supplanting them with neo-patrimonialist (non-)institutions.

The following theoretical propositions summarise the preceding paragraphs.

5 This corresponds to Duverger's (1955:151) dual nature of organisations, where the organisation has a democratic veneer but remains at its heart oligarchic

6 It is important to note that the mere occurrence of political decay or its symptoms does not mean the end of democracy; rather it signifies that the state is weakening and in extreme cases, situations similar to that of Zimbabwe, Ethiopia and others can arise. These are worst-case examples, such as Somalia and Sudan. 
- Political parties seek political power and mobilise support through ideologies that are formulated around the interests of the most important groups in society.

- The interaction of various political parties and ideologies on the inter- and intraparty levels forms party systems that can be classified in various ways according to the levels of competition allowed. In dominant-party systems, low levels of competition exist; in hegemonic systems, competition is actively discouraged.

- A concept for the classification of African political systems is neopatrimonialism, which is a form of elite governance and is thus oligarchic (dominant and/or hegemonic) in nature.

- Patrimonialism uses clientelism and praetorianism as sources of legitimacy, effectiveness and institutional or structural violence (such as systems of institutionalised discrimination or the maintenance of a party militia or paramilitary organisation).

- The occurrence of patrimonialism, clientelism and praetorianism can be described as symptoms of political decay according to Western regime logic.

With these concepts and the relationship between them as described above, historical events can be interpreted and placed within an explanatory framework. The events leading up to the Polokwane conference give insight into the heart of the ANC, the tripartite alliance and, to a certain extent, South Africa as a whole. On the basis of the above-mentioned propositions, an interpretation and evaluation of South Africa's second political transition can be made.

Currently the ANC can be viewed as a dominant party, functioning in a dominant-party system accommodating hegemonic tendencies with strong ideological undertones, where support is mobilised through patrimonial networks and where conflict and instability is prominent when leadership changes are taking place. This becomes more evident in the following sections.

\section{The events leading up to the national conference of the ANC at Polokwane}

In order to understand the various events leading up to Polokwane, it is important to understand the ideology of the broad tripartite alliance and the ANC in particular. It is in terms of this ideology that the above-mentioned groups define themselves and generate support among the people of South Africa. 
This ideological base of the National Democratic Movement in South Africa is the NDR. The importance of this revolution as dogma for the broad church is undeniable. In his closing speech at Polokwane, Zuma reiterated that the NDR is the guiding philosophy in policy formulation and implementation (Duvenhage, 2007:2). In the ANC strategy and tactics document, this "guiding philosophy" is defined as

... a process of struggle that seeks to transfer power to the people and transform society into a non-racial, non-sexist, united, democratic one that changes the manner in which wealth is shared, in order to benefit all the people (ANC, 2007:21).

This process of struggle, this guiding philosophy, this NDR is today as relevant, if not more relevant, than before. To emphasise this the North West Province Premier stated: "I want to assure them that theirs is a legacy we shall protect and defend as we open a new chapter in our National Democratic Revolution." (Modiselle, 2009:5.)

According to the Strategy and Tactics document of the ANC dated 2007, thirteen years after 1994, “... we are only at the beginning of a long journey to a truly united, democratic and prosperous South Africa ..." (ANC, 2007:1). The 1994 elections and the end of apartheid were just the beginning or the first step of what will be a “... fundamental change in society ..." (ANC, 2007:22). The NDR now have national and democratic tasks, and it should strive to realise:

- a united state based on the will of all the people, without for regard race, sex, belief, language, ethnicity or geographic location;

- a dignified and improved quality of life among all the people by providing equal rights and opportunities to all citizens; and

- the restoration of the birthright of all South Africans regarding access to land and other resources (ANC, 2007:3).

The NDR thus provides the frame of reference or paradigm within which the tripartite alliance thinks about:

- the state, the economy, organisational matters, the ideological dimensions of society and the international "... responsibility as one of the battalions of the global army for progressive social change, a disciplined force of the left" (ANC, 2007:19); 
- the past that inflicted much wrong;

- the need for revolution as agent of change;

- a phased process of change - in 1993 the ANC committed to a period of 20 to 25 years to accomplish its strategic goals;

- the unique South African context of the revolution;

- the fundamental societal transformation as the ultimate result of the NDR; and

- the leadership in this process of the ANC.

It is interesting and important to take note of paragraph 230 of the Strategy and Tactics document (ANC, 2007:19). It simply states: "The struggle continues!"

Crucially, at the time leading up to Polokwane, a part of the constituency of the tripartite alliance was disillusioned with the slow progress of the promises inherent in the NDR. When Mbeki fired Zuma in 2005, he created a political opponent and a vocal advocate for this disillusioned constituency. Although Mbeki received the mantle of leader of the ANC and the South African government from Mandela, he was actually from much earlier on, an important functionary in the ANC. According to Gevisser (2007:394), Mbeki permanently changed the image of the ANC from terrorist organisation to government-in-waiting. He went on to establish a reputation as an intellectual, a well-travelled individual and someone with good relations outside of the more single-minded ANC (Gevisser, 2007:395). It is actually these "strong (?)" points that, even in the 1980s, garnered mistrust among the hard-core ANC membership as Mbeki "... managed to seduce white South Africans, particularly Afrikaners, out of the arms of the apartheid government ..." and "... so many in the West, too, into the arms of the ANC" (Gevisser, 2007:395).

Unfortunately, many years later, the former president Mbeki's leadership style was insular and, whilst he achieved success and recognition for himself and his country overseas, people at the grass roots in South Africa began to feel neglected. In 2006, the ANC government was severely criticised for the lack of basic services to many areas in the country and discontent was rife, especially among the poorer black voters, most of whom have always supported the ANC.

They feel forgotten and ignored, their feelings inflamed by their treatment at the hands of the local ruling African National 
Congress ... they complain that they were not consulted at all in the selection of the new ANC candidate ... (Anon., 2006:63).

These feelings were becoming more pervasive throughout the country and importantly also within the ANC, as Mbeki appointed people to the posts of premier without consulting the party. According to Ceruti (2007), a study showed that a third of black and coloured residents in the Gauteng metropolitan area were dissatisfied with service delivery and $44 \%$ of black residents in Gauteng towns. This gave rise to unrest and civil disobedience that

... erupted again in September of 2007. The new protests, mainly over housing, hopped around Soweto, spreading to the townships of south and east Johannesburg, to Alexandra, to Cape Town and beyond ... Police ran out of rubber bullets during a day of skirmishes ... (Ceruti, 2007).

In stark contrast to Mbeki stands Zuma, the son of a domestic worker, who at the age of fifteen took odd jobs to supplement his mother's income. He did not receive any formal schooling, joined the African National Congress at a young age and became an active member of Umkhonto We Sizwe. In 1996, he was arrested and convicted of conspiring to overthrow the government. He was sentenced to ten years' imprisonment, which he served on Robben Island.

After his release, Zuma helped mobilise internal resistance and was instrumental in the re-establishment of ANC underground structures in KwaZulu-Natal. During his career, he lived in several African countries working for the ANC, where he rose rapidly through the ranks to become a member of the ANC National Executive Committee in 1977. After moving to the ANC headquarters in Lusaka in Zambia, he was appointed Head of Underground Structures and shortly thereafter Chief of the Intelligence Department (ANC, 2001). All this led to a very sound reputation within the revolutionary movement, and Zuma became a populist leader that, in contrast to Mbeki's seemingly aloof dictatorial style, can lead any gathering in songs about the struggle, revolution and change.

In 2005, however, Mbeki fired Zuma from his post as Deputy President of the country. This resulted in a party political power struggle and an awakened sense in the ANC for the need of renewal and brought internal party differences to the surface (Duvenhage, 2007: 1 ; Wines, 2007). At this point, the ANC made a recommitment to the NDR, and Zuma seized the opportunity to approach the SACP, COSATU, the ANCYL and the MK veterans; the black voters that felt betrayed by Mbeki's ANC. Forming alliances and portraying himself 
as the people's president, Zuma rescued his political career and formed the influential grouping in the ANC that won his election as President of the ANC and, eventually in 2009, the President of the country. This, despite the allegations of corruption against Zuma, who became the first new martyr for the ANC in the "second struggle", against Mbeki.

The events leading up to Polokwane are characterised by the importance of the NDR and the various interpretations of this ideology by the Zuma grouping versus the Mbeki grouping. Along these ideological (hard-core) lines, the cracks in the once monolithic ANC became apparent to outsiders. The difference in the backgrounds, personalities and leadership styles of the two main protagonists, Zuma and Mbeki, served as beacons for polarisation within the organisation and provided the essential backdrop for the Polokwane conference. Given this backdrop, it is now important to look at the decisions made at the conference.

\section{The main decisions of the National Conference of the ANC at Polokwane}

Thus, the conference at Polokwane took place in an atmosphere of division and conflict in the governing party and its coalition. This was accompanied by high levels of political corruption, nepotism, controversial dismissals (Vusi Pikoli and Nozizwe Madlala-Routledge) and a lack of action against Mbeki-loyalists (Jackie Selebi and Manto Tshabalala-Msimang). Zuma could by then count on the support of the ANCYL, the Woman's League and the majority of the votes from the provinces (Duvenhage, 2007:4). This, as a matter of history, led to the Zuma victory and provides a remarkable insight into the ANC.

The Polokwane conference exposed the deep-rooted divisions in the party. Therefore, the most important decision of Polokwane was to give Zuma a mandate to be the new revolutionary leader who would form the vanguard of the internal renewal of the ANC and by doing so unify the divided house. It is his task to bring the ANC back in-line with the NDR and to bring the government in-line with the party.

This will be done by the implementation of the other important decisions made at Polokwane, which include:

- organisational renewal and strengthening of the ANC in its complementary role as both liberation movement and governing party; 
- focusing the ANC as key strategic centre of power for the achievement of the goals of the NDR;

- the implementation and realisation of the millennium development goals;

- greater social responsibility regarding education and health in general, no-fee schools and housing, general health and unemployment subsidies, and a new dispensation for MK veterans;

- the restructuring and implementation of the land nationalisation laws;

- a balance between economic development and the negation of economic inequality;

- the ending of the floor-crossing laws; and

- the revaluation of the provincial and local governing systems by 2009.

It is important to note that these decisions were reflected in the 2009 Election manifesto of the ANC. In this sense, the measures described above will influence the populace of the country directly and represent the concretisation of the ideological shift within the ANC.

An important backlash in reaction to the decisions of Polokwane as mentioned above has also been felt in the ANC and the country as a whole. A splinter party, the Congress of the People (COPE) was formed to oppose the ANC from within, grabbing support from the heart of the parent organisation. This has angered the ANC and provoked a decidedly undemocratic response among some of the leadership of the tripartite alliance that takes the form of threats, name-calling and, among the grass-roots supporters, violence (Mbanjwa, 2008).

It is clear that the ANC and politics in South Africa emerged very different from the Polokwane conference. The scene was set for a palace revolution last seen in South Africa in the National Party when the F.W. de Klerk grouping supplanted P.W. Botha. The vanguard of the ANC changed, and they were placing their man, by way of a new ideological and personal dispensation in the final position for ascension to power. One patrimonial elite was replaced by another in order to cement the domination of the ANC as party within the South African party system. This process displayed hegemonic, praetorian, and neo-patrimonialist elements. These elements were further emphasised by the 2009 general election. 


\section{The $\mathbf{2 0 0 9}$ election: Polokwane brought to the nation}

The goals formulated at Polokwane and the recommitment to the NDR were expressed in the 2009 Election manifesto of the ANC in the following manner:

The ANC government will:

- Make the creation of decent work opportunities and sustainable livelihoods the primary focus of our economic policies. We will make maximum use of all the means at the disposal of the ANC government, to achieve this ...

- Ensure that macro-economic policy is informed by the priorities that have been set out in this Manifesto ... Economic policy will include measures to decisively address obstacles that limit the pace of employment creation and poverty eradication ...

- Ensure that state-led industrial policy leads to the transformation of the economy ...

- Ensure that a comprehensive package of measures is introduced to promote beneficiation programs, to ensure that the natural wealth of the country is shared ...

- Engage the private financial sector in order to facilitate its transformation and diversification including the development of the co-operative financial institutions as well as ensuring that the sector contributes to investment and developmental priorities of the country.

- Develop programmes to promote the important role of mining and agriculture in employment, meeting basic needs and community development, and commit to continued transformation of these sectors to achieve national goals ...

- Tourism and other services will be supported to expand work for our people.

- Develop and invest in a programme to create large numbers of 'green jobs' ...

- Ensure that the mandates of development finance institutions are clear and truly developmental and that their programmes contribute to decent work outcomes, achievement of our developmental needs and sustainable livelyhoods. 
- Lead a massive public investment programme for growth and employment creation ...

- $\quad$ Step up a massive programme on expanded public works linked to infrastructure and meeting social needs with home-based care, crèches, school cleaning and renovation, community gardens, removal of alien vegetation, tree planting and school feeding.

- In order to avoid exploitation of workers and ensure decent work for all workers as well as to protect the employment relationship, introduce laws to regulate contract work, subcontracting and out-sourcing, address the problem of labour broking and prohibit certain abusive practices. Provisions will be introduced to facilitate unionisation of workers and conclusion of sectoral collective agreements to cover vulnerable workers in these different legal relationships and ensure the right to permanent employment for affected workers ...

- Create an environment for more labour-intensive production methods, procurement policies that support local jobs and building public-private partnerships.

- Vigorously implement broad-based economic empowerment and affirmative action policies and adjust them to ensure that they benefit more broad sections of our people $\cdots$

- Launch a much larger national youth service programme and a new national youth development agency ... (ANC, 2009).

These measures, placing the party at the forefront of radical socioeconomic and political change in South Africa, can be seen as the operationalisation of the Polokwane decisions, the recommitment of the ANC to the NDR and the tangible way this ideology was brought to the people of South Africa. The reaction to this was a resounding vote of confidence.

On national level, the ANC received $65,89 \%$ of the vote, the nearest opposition, the DA (Democratic Alliance) received 16,66\%, followed by COPE at 7,41\%, with the smaller parties losing support and representation. On provincial level, the ANC won major victories in all provinces except the Western Cape, a province that the MK veterans have threatened to make ungovernable (SAPA, 2009). In KwaZulu-Natal where the IFP (Inkata Freedom Party) had a 20\% 
showing, sporadic violence is still common. According to Mangosuthu Buthelezi (Quintal, 2009), violence and intolerance between the ANC and IFP was "very bad"; "The media ... think that by not reporting or highlighting the violence, they will not fan the flames, (so) there is under-reporting." Thus, as illustrated by Figure 2, the ANC (nominally) lost its two-thirds majority, the DA emerged the second strongest party by far, COPE was placed on the map and all the smaller parties lost ground.

\section{Figure 2: The national results of the 2009 election}

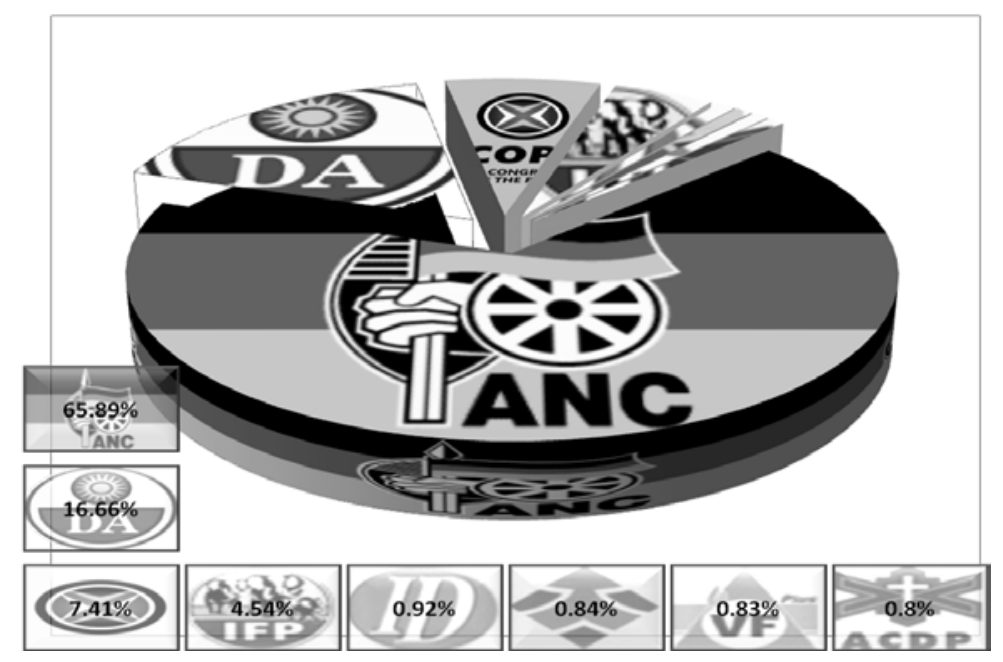

Now the ANC and Zuma in particular have to work towards the fulfilment of the manifesto promises. To this end, the SABC board is being reconstructed. A battle is raging around the Constitution with the legal and civil society accusing the Department of Justice of challenging the supremacy of the Constitution.

They say a draft Bill the department has quietly introduced aims to change the Constitution in a way that will make Parliament's decisions on one particular Act immune to the scrutiny of the Constitution. (Ilham, 2009:1.)

Zuma, under pressure from the trade union that help elect him, wants to create 500000 jobs by the end of 2009. The project, termed the National Jobs Initiative, will cost an estimated R10 billion (Modimoeng, 2009). This is a proverbial drop in the ocean compared with the public works spending programme, for which government is to spend R787 billion over the next three years.

Major investment in power generation, transport networks and telecommunications are in progress, building an environment within which mining and industrial development, tourism, and 
our service economy can prosper, even if the short-term outlook is poor. (Manuel, 2009:11.)

This represents the many faceted changes from the Mbeki into the Zuma era. These changes are described in the next section.

\section{The second political transition in South Africa}

In this part of the article, the theoretical and conceptual tools provided in the first part are utilised to explain the historical events described above. The post-Polokwane environment is then plotted, in order to describe the process of change that is currently underway in South Africa and provide a vision for the future.

As already mentioned, Bratton and Van de Walle (1998:78) describe the apartheid regime as a settler oligarchy, with a colonialist settleronly (apartheid) government. With the 1994 election, this changed and South Africa became a multiparty democracy for the short period it took the ANC to establish unassailable dominance.

Figure 3 illustrates these developments, using the diagram provided by Bratton \& Van de Walle (1997:78) and applied it to the South African situation. A indicates the transition from a settler oligarchy to a multiparty democracy as formalised by the 1994 elections. B indicates the dominance of the ANC in every election since then with huge majorities, despite the DA and, more recently, COPE. C indicates the second political transition in South Africa. Within the broad transition C, several tendencies (T1 to T5) can be identified.

\section{Figure 3: The complexity of the second political transition}
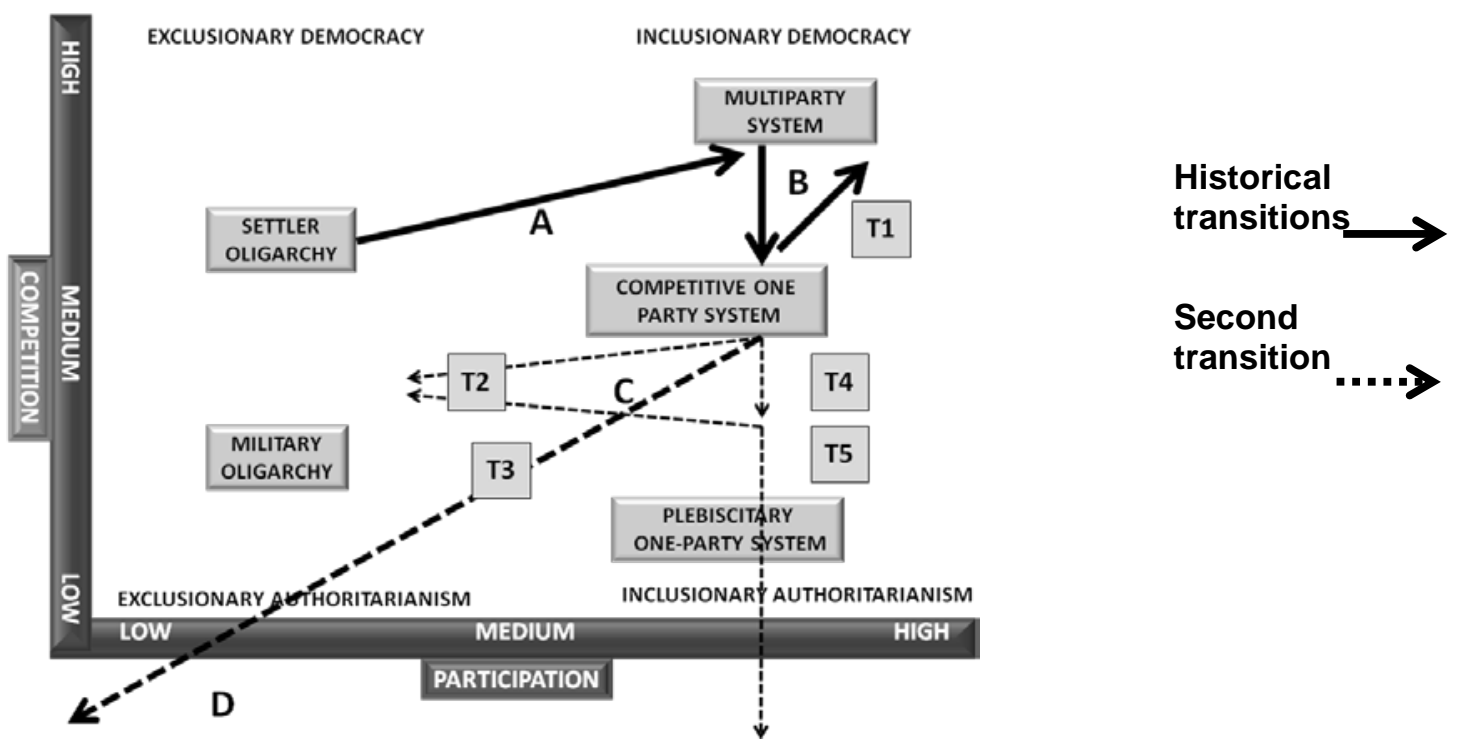
The following explains the figure above (for integration of timelines, compare Figure 4):

A: The first regime change from settler oligarchy (apartheid) to multiparty democracy through the elections of 1994 (Figure 4: first block 1994).

B: The Mandela and Mbeki eras during which the party system in South Africa became a dominant-party system as described in this article (Figure 4: second block 1994-1997 and third block 1997-2004).

C: The second significant transition in South African politics, gaining momentum and at the Polokwane conference, which carried through the 2009 elections and can now be seen as examples of government policy. Herein certain tendencies can be discerned:

T1: The broadening of democracy: COPE (a more centrist party) splintered away from the ANC, the DA became stronger and took over the governance of one of the provinces.

T2: ANC dominance: The ANC is still the dominant political super formation in South African politics with huge victory margins in the 2009 elections and, in some instances, eroding institutions of state in favour of party institutions.

T3: ANC dominance "turbo": A process in which increasing dominance results in lower participation and lower levels of competition.

T4: ANC hegemony: The ANC is dominant with hegemonic (contra-competition) tendencies. Opposition parties are intimidated, inflammatory rhetoric is used and violence is possible.

T5: ANC hegemony "turbo": A process in which increasing hegemony results in lower levels of competition, whilst levels of participation remain high.

D: The result of T3 and T5 in various combinations will be $\mathbf{D}$, continuing patterns of political decay and a possible system implosion as a possible scenario. 
Figure 3 and the six tendencies are the result of the synthesis of theoretical perspectives elaborated on in part one and the historical events, as related later in the article. As such, they represent a vision of the second political transition in South Africa. An evaluatory perspective consisting of the theoretical propositions vis-à-vis the second political transition is now added.

\section{Theoretical propositions and the second political transition}

Thus, the five theoretical statements given in part one of this article can now be expanded using examples given in other parts of the article.

- Political parties seek political power and mobilise support through ideologies that are formulated around the interests of the most important groups in society.

- The ANC recommitted to the NDR (its ideology) in an effort to find its identity, get rid of Mbeki and usher in the Zuma elite who has direct connotations to COSATU, the SACP and the ANCYL. In this process, various factions made various ideologically motivated promises, which the economy might not be strong enough to fulfil.

- The interaction of various political parties and ideologies on the inter- and intraparty levels forms party systems that can be classified in various ways.

- The ANC experienced a period of internal turmoil, despite external (interparty) hegemony. This turmoil redefined the ANC in-line with the NDR through Polokwane and the 2009 elections, but also changed the external (party system) environment with the emergence of COPE and a stronger DA. The ANC also became less tolerant (more hegemonic?) regarding its "right" to govern.

- A concept for the classification of African political systems is neo-patrimonialism, which is a form of elite governance and is thus oligarchic in nature.

- The decrease in tolerance referred to above had neopatrimonialist, clientelist and even praetorian moments as the Mbeki and Zuma factions battled for supremacy. 
- Patrimonialism uses clientelism and praetorianism as sources of legitimacy.

- The changing political environment was accompanied by threats to purge the opposition, kill for Zuma, focus more on the individual and less on economic and state priorities, make the Western Cape ungovernable, as well as violence in KwaZulu-Natal, large-scale corruption, favouritism, nepotism and the undermining of the institutions of state. The promises of the ANC can be seen as a macro-clientelist programme that may not be economically sustainable.

- The occurrence of patrimonialism, clientelism and praetorianism can be described as symptoms of political decay.

- Political decay is a complex phenomenon with a variety of possible outcomes. In as far as the institutions of state seem to be weakening in South Africa, party structures becoming stronger and the idea of a Western (liberal) state mutating into a neo-patrimonialist institution, it can be said that patterns of political decay are evident.

These propositions are now subjected to a short evaluation in the following section and conclusions regarding these propositions are given.

\section{Evaluation and conclusion}

The radical rhetoric forming the shroud of the broad liberationist church became increasingly brazen (and inflammatory) as their candidate (Zuma) was threatened and the 2009 election approached. This reflects the new, more radical or stricter interpretation of the religion (the NDR) of this church. South Africa's second political transition is the result of these new recommitments. Figure 4 offers a contextualisation of this transition by providing a time reference for political change in South Africa. 
Figure 4: Contextualisation of the second political transition

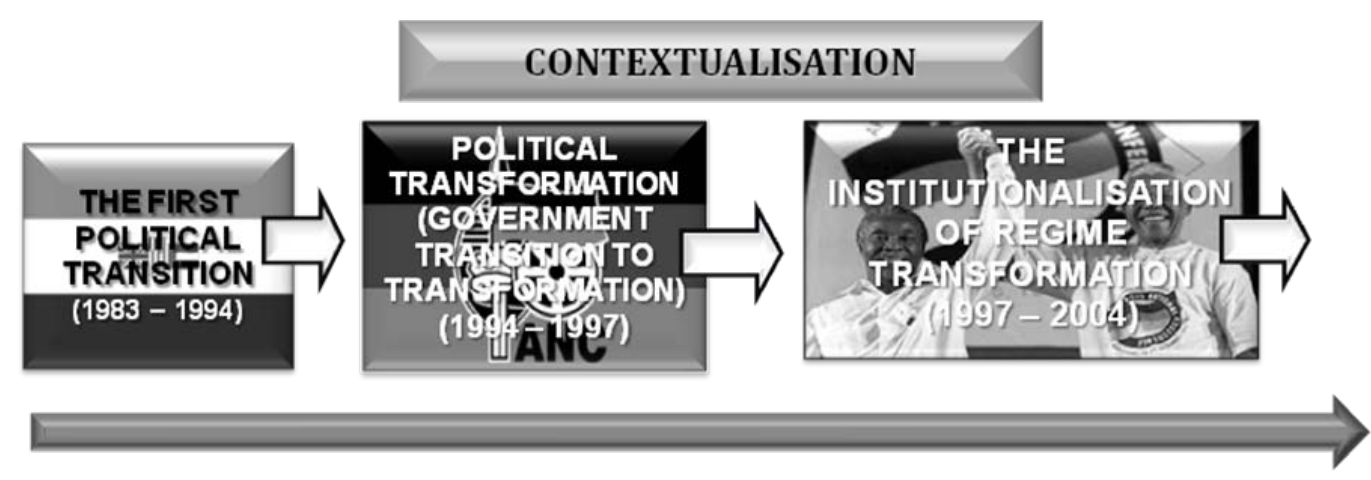

THE PHASES OF POLITICAL CHANGE SINCE 1994

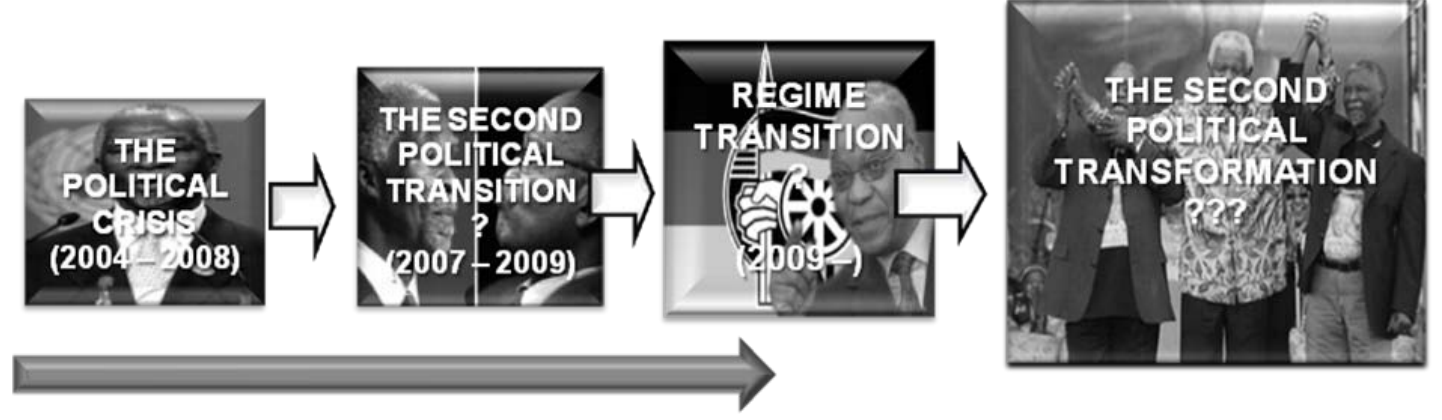

\section{SA FIRST AND SECOND POLITICAL TRANSITION (TRANSFORMATION?)}

Figure 4 describes the flow of political change from 1983 to the present. Invariably the question must now be posed as to the outcome of this transition. In this regard, the following can be concluded:

- As political parties seek power, they formulate, reformulate and recommit to ideologies. In this sense, the recommitment to the NDR was a success for the ANC at Polokwane and in the 2009 general election. It is only logical that they will continue to use the radical NDR to mobilise mass support in the future. The problem with this is that there are promises inherent in the NDR, which if not fulfilled will result in a surfeit of mobilised and dissatisfied participants in the political system.

- The ANC (and the tripartite alliance) have expressed increasing amounts of intolerance (importantly, also towards internal dissidents) especially when they perceived that their agenda was threatened. In essence, this harks back to the roots of the organisation as a warring liberation movement rather than an evolution forward, towards a democratic culture. 
- As one elite replaced the other, the poor got poorer, the doctors went on strike, the teachers proclaimed their dissatisfaction and various patrimonial elite elements of big government battled each other, rather than the problems. This elitist process is not sustainable.

- Should South African society become militarised through the use of militias, paramilitaries or structures to express violent threats or even to bring them into effect, society will degenerate into chaos.

- This will then be the practicality of political decay and the politics of survival where life according to Hobbes (1904) will be "solitary", "poor", "nasty", "brutish" and "short".

The hope must remain that the new democracy in South Africa will continue to grow and prosper despite the circumstances detailed above. It must be remembered that the countries hailed as great democracies around the world today had long periods of difficult gestation through which they evolved and grew into what we see today. The South African democracy is barely twenty years old. Only by being vigilant and by speaking truth to power, as this article has attempted, will a democratic culture continue to evolve.

\section{List of references}

ADAM. H. 1971. Modernizing racial domination: South Africa's political dynamics. Berkeley: University of California.

ANC. 2001. Jacob Zuma. http://www.anc.org.za/people/zuma_j.html Date of access: 12 Jul. 2009.

ANC. 2007. Strategy and tactics of the ANC: building a national democratic society. http://www.anc.org.za/ancdocs/history/conf/conference52/strategy tactics.html. Date of access: 12 Jul. 2009.

ANC. 2009. ANC 2009 election manifesto. http://www.anc.org.za/show.php? doc=elections $/ 2009 / \mathrm{manifesto} / \mathrm{manifesto} . \mathrm{html} \&$ title=2009+Election+Manife sto Date of access: 12 Jul. 2009.

ANON. 2006. A little local trouble. The Economist, 4 Mar.

BALL, A.R. 1993. Modern politics and government. 5th ed. Houndmills: Macmillan.

BEALEY, F. 2003. The Blackwell Dictionary of Political Science. Oxford: Blackwell.

BRATTON, M. \& VAN DE WALLE, N. 1998. Democratic experiments in Africa: regime transitions in comparative perspective. Cambridge: Cambridge University Press.

CERUTI, C. 2007. South Africa: rebirth of a mass movement. International socialism, 116:28, Sept. http://www.isj.org.uk/index.php4?id=362\&issue= 116 Date of access: 12 Jul. 2009.

CLOETE, F., WISSINK, H. \& DE CONING, C., eds. 2006. Improving public policy: from theory to practice. 2nd ed. Pretoria: Van Schaik. 
DUVENHAGE, A. 2007. Die ANC se Polokwane konferensie: paleisrevolusie, politieke tussenspel en verhoogde politieke onstabiliteit. Word in Action, Winter.

DUVERGER, M. 1955. Political parties: their organization and activity in the modern state. London: Methuen.

EASTON, D. 1953. The political system: an inquiry into the state of political science. New York: Knopf.

FERGUSON, P.A. 2006. The politics of regime change in the global era. (In Dyck, R., ed. Studying politics: an introduction to political science. 2nd ed. Toronto: Thompson.)

GENTILI, A.M. 2005. Party, party systems and democratisation in sub-Saharan Africa. Paper read at the Sixth Global Forum on Reinventing Government, Seoul, Republic of Korea, 24-27 May 2005.

GEVISSER, M. 2007. Thabo Mbeki: the dream deferred. Johannesburg: Ball.

HOBBES, T. 1904. Leviathan. Cambridge: Cambridge University Press.

HUNTINGTON, S.P. 2006. Political order in changing societies. London: Yale University Press.

ILHAM, R. 2009. The constitution: just a piece of paper? Mail \& guardian online: 19 Jun. http://www.mg.co.za/article/2009-06-19-the-constitution-just-apiece-of-paper Date of access: 12 Jul. 2009.

MANUEL, T.A. 2009. Budget speech 2009. http://www.info.gov.za/speeches/ budget/speech2009.pdf Date of access: 12 Jul. 2009.

MBANJWA, X. 2008. Kill Lekota, rivals chant. IOL: 24 Oct. http://www.iol.co.za/ index.php?click_id=13\&set_id=1\&art_id=vn20081024052810794C842274 Date of access: 11 Jul. 2009.

MICHELS, R. 1959. Political parties. New York: Dover.

MKHWANAZI, S. 2008. Vavi sticks to guns on "kill" call. IOL: 23 Jun. http://www.iol.co.za/index.php?set_id=1\&click_id=6\&art_id=vn2008062305 5309875C639539 Date of access: 21 Jul. 2009.

MODIMOENG, K. 2009. Cost of creating 500000 jobs. Business Times, 10 Jun. http://www.thetimes.co.za/Business/BusinessTimes/Article1.aspx?id=1014 949 Date of access: 12 Jul. 2009.

MODISELLE, M. 2009. State of the province address by the premier of the North West province. 12 Jun.

NEWTON, K. \& VAN DETH, J.W. 2005. Foundations of comparative politics: democracies of the modern world. Cambridge: Cambridge University Press.

OXFORD ENGLISH DICTIONARY ONLINE. 2009. Palace revolution. Date of access: 11 Jul. 2009.

PLOWRIGHT, A. 2008. Analysts: violence jolts complacent ANC. Mail \& Guardian online: 29 May. http://www.mg.co.za/article/2008-05-29analysts-violence-jolts-complacent-anc Date of access: 11 Jul. 2009.

QUINTAL, A. 2009. Buthelezi saddened by chasm between parties. IOL: 7 Jun. http://www.iol.co.za/index.php?set_id=1\&click_id=6\&art_id=vn2009060707 3413379C933686 Date of access: 12 Jul. $200 \overline{9}$.

SAPA

see SOUTH AFRICAN PRESS ASSOCIATION

SARTORI, G. 1976. Parties and party systems: a framework for analysis. Cambridge: Cambridge University Press.

SCHUMPETER, J.A. 1942. Capitalism, socialism and democracy. London: Allen \& Unwin. 
SOUTH AFRICAN PRESS ASSOCIATION. 2008a. We are prepared to die for Zuma. Mail \& guardian online: 17 Jun. http://www.mg.co.za/article/ 200806-17-we-are-prepared-to-die-for-zuma Date of access: 11 Jul. 2009.

SOUTH AFRICAN PRESS ASSOCIATION. 2008b. Purge counterrevolutionaries. News24: 13 Jul. http://www.news24.com/News24/South_ Africa/Politics/0,,2-7-12_2356831,00.html Date of access: 11 Jul. 2009.

SOUTH AFRICAN PRESS ASSOCIATION. 2008c. ANCYL: if you want war, we will give you war. IOL: 11 Sept. 2008 http://www.iol.co.za/index. php?sf=105\&set_id=1\&click_id=13\&art_id=nw20080911141538545C7461 32 Date of access: 11 Jul. 2009.

SOUTH AFRICAN PRESS ASSOCIATION. 2008d. Police keep peace at rally. News24: 27 Oct. http://www.news24. com/Content/SouthAfrica/Politics/ 1057/b6a99d93c0074fa0b77c7f5e639f9369//Police_keep_peace_at_rally Date of access: 11 Jul. 2009.

SOUTH AFRICAN PRESS ASSOCIATION. 2009. ANC, allies lay into Zille. Mail \& guardian online: 12 May. http://www.mg.co.za/article/2009-05-12-ancallies-lay-into-zille Date of access: 11 Jul. 2009.

THOMPSON, A. 2003. An introduction to African politics. London: Routledge.

WINES, M. 2007. Party power struggle enthralls South Africa. New York times, 12 Oct. http://www.nytimes.com/2007/10/12/world/africa/12safrica.html? r=1\&pagewanted=all Date of access: 12 Jul. 2009.

\section{Key concepts:}

parties and party systems

patrimonialism

Polokwane conference

second political transition

\section{Kernbegrippe:}

partye en partystelsels

patrimonialisme

Polokwane konferensie

tweede politieke transisie 